\title{
Is there any relationship between sudden sensorineural hearing loss and protein $\mathrm{Z}$ plasma levels?
}

\author{
Protein $Z$ plazma düzeyleri ile ani işitme kaybı arasinda ilişki var mıdır? \\ Aydın Acar, ${ }^{1}$ Zeynel Öztürk, ${ }^{2}$ Melih Çayönü, ${ }^{1}$ Saltuk Buğra Kılınç, ${ }^{1}$ Turan Turhan, ${ }^{3}$ \\ Esin Çalcı, ${ }^{3}$ Oğuzhan Oğuz, ${ }^{3}$ Ayşe İriz ${ }^{4}$ \\ ${ }^{1}$ Department of Otolaryngology, Ankara Numune Training and Research Hospital, Ankara, Turkey \\ ${ }^{2}$ Nişantaşı University Technical College, İstanbul, Turkey \\ ${ }^{3}$ Department of Biochemistry, Ankara Numune Training and Research Hospital, Ankara, Turkey \\ ${ }^{4}$ Department of Otolaryngology, Medical Faculty of Gazi University, Ankara, Turkey
}

\begin{abstract}
Objectives: This study aims to evaluate the relationship between sudden sensorineural hearing loss and protein $\mathrm{Z}$ plasma levels.

Patients and Methods: Twenty patients with sudden sensorineural hearing loss (14 males; 6 females; mean age $51.6 \pm 14.6$ years; range 23 to 75 years) and 30 healthy subjects without any hearing problems (14 males, 16 females; mean age $46.8 \pm 8.9$ years; range 30 to 64 years) were investigated. Protein C, protein $S$, and protein $\mathrm{Z}$ plasma levels were measured.

Results: When protein $S$ and protein $C$ levels were compared between the study groups, we did not find a statistically significant difference $(\mathrm{p}=0.78$ and $\mathrm{p}=0.44)$, whereas, protein $\mathrm{Z}$ plasma levels were found to be considerably lower in the sudden sensorineural hearing loss group than in the control group, and the difference was statistically significant $(\mathrm{p}<0.001)$.
\end{abstract}

Conclusion: Vascular causes may be involved in the etiology of sudden hearing loss. Changes in protein $\mathrm{Z}$ plasma levels might be associated with arterial thromboembolism or venous thrombosis in patients with sudden sensorineural hearing loss.

Keywords: Etiology; protein Z; sudden sensorineural hearing loss; thromboembolism.

Sudden sensorineural hearing loss (SSNHL), first defined by De Kleyn in 1944, is one of the most challenging issues in otolaryngology. ${ }^{[1]}$ Idiopathic SSNHL, the acute onset of hearing loss of at least $30 \mathrm{~dB}$ in three connected
$\ddot{O} Z$

Amaç: $\mathrm{Bu}$ çalışmada protein $\mathrm{Z}$ plazma düzeyleri ile ani işitme kaybı arasında ilişki değerlendirildi.

Hastalar ve Yöntemler: Ani işitme kaybı olan 20 hasta (14 erkek, 6 kadın; ort. yaş $51.6 \pm 14.6$ yıl; dağılım $23-75$ yıl) ve herhangi bir işitme sorunu olmayan 30 sağlıklı birey (14 erkek, 16 kadın; ort. yaş 46.8 \pm 8.9 yıl; yaş aralığı 30-64 yıl) araştırmaya dahil edildi. Protein $C$, protein $S$ ve protein $Z$ plazma düzeyleri ölçüldü.

Bulgular: Çalışma grupları arasında protein $S$ ve protein $C$ düzeyleri karşılaştırıldığında istatistiksel olarak anlamlı bir fark bulunmazken ( $p=0.78$ ve $p=0.44)$, kontrol grubuna göre ani işitme kaybı olan grupta protein $\mathrm{Z}$ plazma düzeylerinin önemli ölçüde düşük olduğu bulundu ve fark istatistiksel olarak anlamlıdı $(\mathrm{p}<0.001)$.

Sonuç: Damarsal nedenler ani işitme kaybı etyolojisinde yer alabilir. Ani işitme kaybı olan hastalarda protein $\mathrm{Z}$ plazma düzeylerindeki değişim arteriyel tromboembolizm veya venöz tromboz ile ilişkili olabilir.

Anahtar sözcükler: Etyoloji; protein Z; ani işitme kaybı; tromboembolizm.

frequencies occurring instantaneously or over a period of up to three days has an estimated incidence between 10 and 20 per 100.000 persons per year. ${ }^{[2,3]}$ Etiological factors can be found in only $10-15 \%$ of SSNHL 
patients, while other patients remain idiopathic. Others define SSNHL as a rapid-onset sensorineural hearing loss that develops within 24 hours. ${ }^{[4,5]}$ In a recent systematic analysis of 23 research papers, Chau et al. ${ }^{[6]}$ demonstrated that $71 \%$ of SSNHL cases were classified as idiopathic SSNHL because no underlying pathology could be found. In $13 \%$ of cases, infection was shown to be the culprit, whereas $5 \%$ of cases were attributed to otologic etiology, $4 \%$ to trauma, $3 \%$ to hematologic causes, $2 \%$ to neoplasia, and another $2 \%$ to other causes. ${ }^{[6]}$ Idiopathic SSNHL occurs mainly in patients between the ages of 30 and 60 years, with equal sex distribution, and can be devastating for the patient. It is almost always unilateral and is commonly associated with tinnitus and aural fullness. Therefore, SSNHL should be treated as a medical emergency. Multiple treatment protocols and agents have been proposed to treat SSNHL. Treatment options include steroids, antivirals, vasodilators, diuretics, hyperbaric oxygen therapy, and vitamins. ${ }^{[7,8]} \mathrm{A}$ maximum of 32 to $65 \%$ of cases of SSNHL may recover spontaneously.

The vitamin $\mathrm{K}$-dependent anticoagulant plasma glycoprotein protein $\mathrm{Z}(\mathrm{PZ})$ was first isolated from bovine plasma in 1977 and in 1984 from human plasma and was shown to exert an important role in the regulation of the coagulation cascade. ${ }^{[9,10]}$ While in vitro studies showed that bovine $\mathrm{PZ}$ could promote the assembly of thrombin with phospholipid surfaces, thereby enhancing coagulation, the human $\mathrm{PZ}$ form binds to thrombin poorly, with very little impact on the association of thrombin binding with phospholipids. More recent studies showed that PZ forms a calcium ion-dependent complex with Factor Xa on phospholipid surfaces, thereby serving as a cofactor for the inhibition of Factor $\mathrm{Xa}$ by a $\mathrm{PZ}$-dependent protease inhibitor (ZPI). ${ }^{[1]}$ Deficiency in $\mathrm{PZ}$ secretion and/or function was linked with a procoagulant state and several thrombotic disorders, including arterial and venous thrombosis.

Proteins $\mathrm{C}, \mathrm{S}$, and $\mathrm{Z}$ are vitamin $\mathrm{K}$-dependent glycoproteins. These proteins had an important role in regulating the coagulation system. Deficiencies in these proteins lead to an increased risk of venous thromboembolism. Prothrombin time (PT) and activated partial thromboplastin time (aPTT) are commonly investigated markers in patients with coagulation disorders. Prothrombin time and aPTT measure the extrinsic and intrinsic pathways of coagulation, respectively. These markers are useful in the case of proteins $\mathrm{C}, \mathrm{S}$, and $\mathrm{Z}$ deficiency.

However, coagulation markers for SSNHL are widely investigated in different studies, and the possible effect of the mentioned parameters is still unknown.
Thus, the aim of this study was to investigate the possible relationship between sudden hearing loss and protein $\mathrm{Z}$ plasma levels.

\section{PATIENTS AND METHODS}

The study was carried out in collaboration with the Otorhinolaryngology and Biochemistry Clinics of Ankara Numune Training and Research Hospital. The study was performed prospectively by including 20 patients with SSNHL (14 males; 6 females; mean age $51.6 \pm 14.6$ years; range ages 23 to 75 years), and 30 in the control group, (14 males, 16 females; mean age $46.8 \pm 8.9$ years; range 30 to 64 years). Patients were informed about their disease and the treatment they would receive; they consented to give blood and have the blood used in the study. The study was conducted in accordance with the principles of the Declaration of Helsinki and approved by the ethical committee of Ankara Numune Training and Research Hospital (573/2013). All the patients were studied with hemogram, routine biochemistry, hemostasis parameters PT, aPTT, international normalized ration (INR), protein $\mathrm{C}(\mathrm{PC})$, protein $\mathrm{S}(\mathrm{PS}), \mathrm{PZ}$, thyroid function $\left(\mathrm{sT}_{3}, \mathrm{sT}_{4}, \mathrm{TSH}\right)$, and an audiogram with high-resolution temporal bone computed tomography or magnetic resonance imaging. None of the patients used anticoagulant medicine before treatment, and all the patients' liver function tests were within the reference range. None of the SSNHL patients had developed thromboembolism. Blood samples were collected from all participants. Two types of blood collection tubes [red-top tube (standard empty vacuum container) and citrate-containing tube] were used. To avoid the coagulation activation effect, the first $1 \mathrm{~mL}$ of blood was discarded. All samples were centrifuged at $1000 \mathrm{~g}$ for 15 minutes and then samples were stored at $-80{ }^{\circ} \mathrm{C}$ until analysis. The measurements of $\mathrm{PZ}$ concentrations were determined in plasma by using the enzyme-linked immunosorbent assay Kit For Protein $\mathrm{Z}$ (PROZ; Houston/USA, USCN). An ELISA microplate strip washer (EXL50; BioTek Instruments, USA) and an ELISA microplate reader (ELX808; BioTek Instruments, USA) were used to perform measurements. The reportable range was $0.156-10 \mathrm{ng} / \mathrm{mL}$. The assay had a precision of less than $10 \%$.

Protein C and PS concentrations were determined in plasma by using cholorimetric and formation clotting methods, respectively. Measurements were performed with a Simultaneous Thermal Analyzer (STA; Diagnostica Stago, Parsippany, NJ, USA).

\section{Statistical analysis}

Data analyses were performed using the IBM SPSS version 21.0 software (IBM Corporation, 
Armonk, NY, USA). The normal distribution of the considered variables was evaluated first using the Shapiro-Wilk test. The subjects' demographic data were compared using the Mann-Whitney U test or chi-square test. The correlation analysis was done with Spearman's Rho test. The level of significance was set at $p<0.05$.

\section{RESULTS}

There was no significant difference between the two groups in terms of gender $(p=0.24)$. While there were no significant differences between levels of PS and PC in the patient group and the control group (respectively $\mathrm{p}=0.78$ and $\mathrm{p}=0.44$ ), the $\mathrm{PZ}$ levels in the patient group were considerably lower than the PZ levels in the control group; the difference was found to be statistically significant $(\mathrm{p}<0.001)$ (Table 1$)$.

\section{DISCUSSION}

The major finding of the current investigation was the significant difference between study groups in terms of protein $Z$ plasma levels. As mentioned in the result section, the protein $Z$ plasma levels were significantly lower in patients with SSNHL when compared with the control group.

Etiology can be determined in only $10-15 \%$ of SSNHL patients, and most (71\%) of the cases were classified as idiopathic SSNHL, because no underlying pathology could be found. ${ }^{[4]}$ In $13 \%$ of cases, infection was shown to be the culprit, whereas $5 \%$ of the cases were attributed to an otologic etiology, $4 \%$ to trauma, $3 \%$ to hematologic causes, $2 \%$ to neoplasia, and another $2 \%$ to other causes. ${ }^{[6]}$

Protein $\mathrm{Z}$ is a $62 \mathrm{kDa}$ vitamin $\mathrm{K}$-dependent singlechain glycoprotein consisting of 360 amino acids containing the $\mathrm{N}$-terminal $\gamma$-carboxyglutamic acid domain necessary for its effective secretion, followed by two epidermal growth factor-like domains, and a C-terminal pseudocatalytic domain. ${ }^{[10]}$ Protein $Z$ acts

\section{Table 1}

Protein $\mathrm{Z}$, protein S, and protein C levels comparison of patient and control groups

\begin{tabular}{|lcccc|}
\hline \multicolumn{4}{|c|}{ patient and control groups } \\
\hline & $\begin{array}{c}\text { Patient group } \\
(\mathrm{ng} / \mathrm{mL})\end{array}$ & & $\begin{array}{c}\text { Control group } \\
(\mathrm{ng} / \mathrm{mL})\end{array}$ & \\
\cline { 2 - 2 } & Mean $\pm \mathrm{SD}$ & & Mean $\pm \mathrm{SD}$ & $p^{*}$ \\
\hline Protein $Z$ & $1946 \pm 263$ & & $2273 \pm 162$ & $<0.001$ \\
Protein S & $88.2 \pm 25.4$ & & $88.3 \pm 19.1$ & 0.78 \\
Protein C & $113 \pm 40.2$ & & $108.3 \pm 14.4$ & 0.44 \\
\hline * Mann Whitney U test. & & & \\
\hline
\end{tabular}

as a cofactor for the $72 \mathrm{kDa}$ serpin $\mathrm{ZPI}$, which rapidly inhibits Factors $\mathrm{Xa}$ and $\mathrm{Xla}$, hence reducing thrombin generation. ${ }^{[10-12]}$ Relative to $\mathrm{PZ}, \mathrm{ZPI}$ is present in plasma at higher levels relative to $\mathrm{PZ}$, where it binds all $\mathrm{PZ}$ in a 1:1 ratio, hence circulating as a stable PZ/ZPI complex, with virtually no free $\mathrm{PZ}$ detected. ${ }^{[13,14]}$

Mean protein $\mathrm{Z}$ plasma levels ranged from 1.16 to $2.71 \mu \mathrm{g} / \mathrm{mL}$ and were influenced by genetic and nongenetic factors, including chronic liver disease, age, gender, vitamin $\mathrm{K}$ levels, concurrent use of anticoagulants, pregnancy, and ethnic origin. ${ }^{[9,15]}$ Protein $Z$ plasma levels rapidly increase during the first months of childhood, then slowly taper off, with adult levels reached during puberty, and higher PZ levels were reported in men than in women. ${ }^{[16,17]}$ Protein $\mathrm{Z}$ plasma levels are reduced during inflammatory episodes. Contradictory findings were also reported, with both increased and decreased PZ levels described in obese individuals; this was attributed to altered inflammatory cytokine expression associated with obesity, the presence of anti-PZ antibodies, the ethnic background of study subjects, and possibly increased excretion of PZ. ${ }^{[18-20]}$ Compared to studies on PZ levels, only four studies addressed plasma ZPI levels but had inconclusive findings. An association of reduced ZPI levels, peripheral arterial disease, and venous thrombosis was documented, while no differences in ZPI levels were reported between normal controls and antiphospholipid antibody-positive cases. ${ }^{[7,21]}$

Protein $Z$ deficiency $(<1 \mu \mathrm{g} / \mathrm{mL})$ was linked with a procoagulant state, associated with excessive Factor $\mathrm{Xa}$ secretion and thrombin production. ${ }^{[13,17]} \mathrm{A}$ recent meta analysis demonstrated that reduced $\mathrm{PZ}$ levels were linked with an increased risk of thrombotic events, such as arterial vascular and venous thromboembolic diseases. ${ }^{[21]}$ Whether $\mathrm{PZ}$ deficiency constitutes an independent risk factor for thrombosis is inconclusive, since the association of $\mathrm{PZ}$ deficiency with increased risk of thrombosis was reported in the presence of other prothrombotic risk factors such as factor $\mathrm{V}$ Leiden prothrombin mutation and hyperhomocysteinemia. ${ }^{[17,22]}$ It was further suggested that PZ deficiency did not constitute an independent risk factor for venous thrombosis (VT), but only increased the VT risk with factor V Leiden. Furthermore, a rare inherited coagulation disorder, hereditary combined vitamin K-dependent clotting factor deficiency, was reported. ${ }^{[23]}$

We could not find articles on the subject of connections between PZ and SSNHL in the literature. However, there are many studies of relationships with PZ/ZPI complex levels between subject areas in the colon, and small lung cell, breast, stomach, pancreas, and liver cancers, as well as multiple myeloma (MM), idiopathic 
thrombocytopenic purpura (ITP), and in hematological diseases such as hemophilia A (HA) which are formed venous thrombosis and habitual abortion.

Thromboembolic episodes are the most common complications and the second-leading cause of death in cancer patients. ${ }^{[2]]}$ It is widely documented that coagulation system proteins play a role in cancer growth and metastatic dissemination. ${ }^{[25-27]}$

Protein $\mathrm{Z}$ plasma levels are used for the diagnosis of $\mathrm{MM}$ in patients with bleeding or thrombosis and also used for following the efficiency of MM treatment. According to the study, conducted by the Bolkun et al., ${ }^{[28]}$ it was found that there was no significant difference between the serum PZ levels of healthy people and patients with MM, whereas it was found to be a significant difference between patients with stage 3 disease and stage 1 disease in terms of $\mathrm{PZ}$ levels. Also while the treatment of MM thrombosis by thalidomide is used alone, the risk of thromboses and thromboembolism is less than 5\%; by adding dexamethasone to the treatment, this risk rises to $14 \%$, and doxorubicin, cyclophosphamide, and melfen antineoplastics further increase this risk.

Martinelli et al., ${ }^{[29]}$ said that if a very low PZ level could serve as an isolated venous thrombosis risk factor, moderate $\mathrm{PZ}$ deficiency certainly would increase the venous thromboembolic risk of other well-known prothrombotic risk factors. Additionally, Cobankara et al. ${ }^{[30]}$ showed a significantly higher $\mathrm{PZ}$ concentration in patients with ITP. This clinical observation, suggested by the author, might be attributed to more hemostatically active residual platelets. Bolkun et al., ${ }^{[28]}$ have found in their study that in patients with severe $\mathrm{HA}(\mathrm{F} 8<1 \%)$ and in patients diagnosed with PZ/ZPI complex, levels are significantly lower, and determined that there is no relationship in the remaining patients. ${ }^{[28]}$

Pregnancy is associated with a state of hypercoagulation linked to excessive thrombin generation, which is crucial for controlling bleeding at delivery. ${ }^{[31,32]}$ Growing evidence implicates coagulation abnormalities with adverse pregnancy outcomes, including recurrent and nonrecurrent pregnancy losses, intrauterine growth retardation, placental abruption, intrauterine fetal death, preeclampsia, and maternal or neonatal thrombosis. ${ }^{[32,33]}$ In addition, a decreased quantity of natural anticoagulants, such as PS and PC, and reduction in overall fibrinolytic activity accompany most pregnancy complications. ${ }^{[34]}$ Progressively higher PZ levels were seen with gestational age in normal pregnancies, especially among obese pregnant women, and were attributed to pregnancy-associated imbalance of fibrinolytic and hemostatic mechanisms. ${ }^{[35,36]}$ Protein
$\mathrm{Z}$ plasma levels correlated with gestational age, evidenced by the progressive increases in PZ levels (20\%) during the three trimesters of pregnancy, which were attributed to compensatory mechanisms induced by increased Factor Xa concentrations, and decline thereafter by as much as $30 \%$ to levels below those of the first trimester. The increase in PZ levels becomes attenuated in patients with abnormal pregnancy outcomes, including low birthweight babies or gestational hypertension or diabetes mellitus. ${ }^{[37,38]}$ Reduced PZ levels $(<1 \mu \mathrm{g} / \mathrm{mL})$ were linked with several pregnancy complications including fetal demise, preeclamsia, small-for-gestational age, intrauterine growth restriction, HELLP syndrome, and idiopathic recurrent miscarriage. ${ }^{[37-41]}$

As is known, approximately $3 \%$ of the etiology of SSNHL is from the return of venous thromboembolism, which is obstructing the circulation in the labyrinthine artery. Inadequate and/or ineffective release of ZP/ZPI complex may also participate the pathophysiology of SSNHL, particularly in patients with idiopathic SSNHL. In our study, 20 people who was diagnosed as SSNHL and had not a history of pre-owned venous thrombosis, arterial thromboembolism and problematic pregnancy were compared with 30 participants who had not a problem with their hearing and who not a history pre-owned venous thrombosis, arterial thromboembolism and problematic pregnancy in terms of PZ, PS and PC levels. Statistically significant difference was not found in PS and PC levels between the groups $(p=0.78, p=0.44)$, whereas, PZ levels of the patients with SSNHL were significantly lower than the PZ levels of participants in the control group $(p<0.001)$. As a result of low PZ levels, particularly in the cochlear apical segments, including nutrition and arterial thrombosis in the venous anastomosis network and in the inner ear limited/or may cause micro-emboli, causing SSNHL.

In conclusion, according to our study decreased PZ levels might be one of the possible causes of SSNHL. When the current literature was evaluated among the known causes, 3\% of SSNHL cases were due to hematologic pathologies. Protein $Z$ and a low vitamin $\mathrm{K}$-dependent anticoagulant can cause various thrombotic and thromboembolic events. Protein Z plasma levels of the patients in our study group were significantly lower than in the control group. However, further studies are needed to investigate the relationship betweeen thromboembolic events and SSNHL.

\section{Declaration of conflicting interests}

The authors declared no conflicts of interest with respect to the authorship and/or publication of this article. 


\section{Funding}

The authors received no financial support for the research and/or authorship of this article.

\section{REFERENCES}

1. Seggas I, Koltsidopoulos P, Bibas A, Tzonou A, Sismanis A. Intratympanic steroid therapy for sudden hearing loss: a review of the literature. Otol Neurotol 2011;32:29-35.

2. National Institute on Deafness and Other Communication Disorders. Sudden deafness. Bethesda: National Institutes of Health; 2000

3. Finger RP, Gostian AO. Idiopathic sudden hearing loss: contradictory clinical evidence, placebo effects and high spontaneous recovery rate--where do we stand in assessing treatment outcomes? Acta Otolaryngol 2006;126:1124-7.

4. O'Malley MR, Haynes DS. Sudden hearing loss. Otolaryngol Clin North Am 2008;41:633-49.

5. Conlin AE, Parnes LS. Treatment of sudden sensorineural hearing loss: I. A systematic review. Arch Otolaryngol Head Neck Surg 2007;133:573-81.

6. Chau JK, Cho JJ, Fritz DK. Evidence-based practice: management of adult sensorineural hearing loss. Otolaryngol Clin North Am 2012;45:941-58.

7. Saeki N, Kitahara M. Saeki N, Kitahara M. Acta Otolaryngol Suppl 1994;510:56-61.

8. Kuhn M, Heman-Ackah SE, Shaikh JA, Roehm PC. Sudden sensorineural hearing loss: a review of diagnosis, treatment, and prognosis. Trends Amplif 2011;15:91-105.

9. Broze GJ Jr. Protein Z-dependent regulation of coagulation. Thromb Haemost 2001;86:8-13.

10. Vasse M. Protein $Z$, a protein seeking a pathology. Thromb Haemost 2008;100:548-56.

11. Huang X, Yan Y, Tu Y, Gatti J, Broze GJ Jr, Zhou A, et al. Structural basis for catalytic activation of protein $\mathrm{Z}$-dependent protease inhibitor (ZPI) by protein $\mathrm{Z}$. Blood 2012;120:1726-33.

12. Koren-Michowitz M, Rahimi-Levene N, Volcheck Y, Garach-Jehoshua O, Kornberg A. Protein $Z$ and its role in venous and arterial thrombosis. Isr Med Assoc J 2006;8:535.

13. Han X, Fiehler R, Broze GJ Jr. Characterization of the protein $Z$-dependent protease inhibitor. Blood 2000;96:3049-55.

14. Corral J, González-Conejero R, Hernández-Espinosa D, Vicente V. Protein Z/Z-dependent protease inhibitor (PZ/ ZPI) anticoagulant system and thrombosis. Br J Haematol 2007;137:99-108.

15. Al-Shanqeeti A, van Hylckama Vlieg A, Berntorp E, Rosendaal FR, Broze GJ Jr. Protein Z and protein $Z$-dependent protease inhibitor. Determinants of levels and risk of venous thrombosis. Thromb Haemost 2005;93:411-3.

16. Huang X, Dementiev A, Olson ST, Gettins PG. Basis for the specificity and activation of the serpin protein $Z$-dependent proteinase inhibitor (ZPI) as an inhibitor of membraneassociated factor Xa. J Biol Chem 2010;285:20399-409.

17. Gowri V, Mathew M, Gravell D, AlFalahi K, Zakwani I, Ganguly SS, et al. Protein Z levels in pregnant Omani women: correlation with pregnancy outcome. J Thromb Thrombolysis 2011;32:453-8.

18. Undar L, Karadoğan I, Oztürk F. Plasma protein $Z$ levels inversely correlate with plasma interleukin-6 levels in patients with acute leukemia and non-Hodgkin's lymphoma. Thromb Res 1999;94:131-4.

19. Vasse M, Denoyelle C, Legrand E, Vannier JP, Soria C. Weak regulation of protein $Z$ biosynthesis by inflammatory cytokines. Thromb Haemost 2002;87:350-1.

20. Ramsay JE, Stewart F, Friel H, Walker ID, Greer IA, $\mathrm{McC}$ oll MD. Protein $Z$ in pregnancy: exaggerated rise in obese women. J Thromb Haemost 2005;3:2584-6.

21. Sofi F, Cesari F, Abbate R, Gensini GF, Broze G Jr, Fedi S. A meta-analysis of potential risks of low levels of protein $\mathrm{Z}$ for diseases related to vascular thrombosis. Thromb Haemost 2010;103:749-56.

22. Kemkes-Matthes B, Matthes KJ. Protein Z, a new haemostatic factor, in liver diseases. Haemostasis 1995;25:312-6.

23. Napolitano M, Mariani G, Lapecorella M. Hereditary combined deficiency of the vitamin K-dependent clotting factors. Orphanet J Rare Dis 2010;5:21.

24. Bick RL. Coagulation abnormalities in malignancy: a review. Semin Thromb Hemost 1992;18:353-72.

25. Zacharski LR, Wojtukiewicz MZ, Costantini V, Ornstein DL, Memoli VA. Pathways of coagulation/fibrinolysis activation in malignancy. Semin Thromb Hemost 1992;18:104-16.

26. Sierko E, Wojtukiewicz MZ, Zimnoch L, Tokajuk P, Ostrowska-Cichocka K, Kisiel W. Co-localization of Protein Z, Protein Z-Dependent protease inhibitor and coagulation factor $X$ in human colon cancer tissue: implications for coagulation regulation on tumor cells. Thromb Res 2012;129:112-8.

27. Sierko E, Wojtukiewicz MZ, Zimnoch L, OstrowskaCichocka K, Tokajuk P, Ramlau R, et al. Protein Z/protein $Z$-dependent protease inhibitor system in human nonsmall-cell lung cancer tissue. Thromb Res 2012;129:92-6.

28. Bolkun L, Piszcz J, Oleksiuk J, Luksza E, Galar M, Szumowska A, et al. Protein $\mathrm{Z}$ concentration in multiple myeloma patients. Thromb Res 2011;128:401-2.

29. Martinelli I, Razzari C, Biguzzi E, Bucciarelli P, Mannucci PM. Low levels of protein $Z$ and the risk of venous thromboembolism. J Thromb Haemost 2005;3:2817-9.

30. Cobankara V, Ozatli D, Haznedaroglu I. Circulating Protein $-Z$ in reactive versus primary thrombocytosis and in an ITP. Nagoya Med J 1999;43:65-72.

31. Kist WJ, Janssen NG, Kalk JJ, Hague WM, Dekker GA, de Vries JI. Thrombophilias and adverse pregnancy outcome - A confounded problem! Thromb Haemost 2008;99:77-85.

32. Pabinger I. Thrombophilia and its impact on pregnancy. Hamostaseologie 2008;28:130-4.

33. Michels TC, Tiu AY. Second trimester pregnancy loss. Am Fam Physician 2007;76:1341-6.

34. Thornton P, Douglas J. Coagulation in pregnancy. Best Pract Res Clin Obstet Gynaecol 2010;24:339-52.

35. Ramsay JE, Stewart F, Friel H, Walker ID, Greer IA, McColl MD. Protein $Z$ in pregnancy: exaggerated rise in 
obese women. J Thromb Haemost 2005;3:2584-6.

36. Kusanovic JP, Espinoza J, Romero R, Hoppensteadt D, Nien JK, Kim CJ, et al. Plasma protein $Z$ concentrations in pregnant women with idiopathic intrauterine bleeding and in women with spontaneous preterm labor. J Matern Fetal Neonatal Med 2007;20:453-63.

37. Erez O, Hoppensteadt D, Romero R, Espinoza J, Goncalves $\mathrm{L}$, Nien JK, et al. Preeclampsia is associated with low concentrations of protein Z. J Matern Fetal Neonatal Med 2007;20:661-7.

38. Gowri V, Mathew M, Gravell D, AlFalahi K, Zakwani I, Ganguly SS, et al. Protein $Z$ levels in pregnant Omani women: correlation with pregnancy outcome. J Thromb Thrombolysis 2011;32:453-8.

39. Bretelle F, Arnoux D, Shojai R, D'Ercole C, Sampol J, Dignat $F$, et al. Protein $Z$ in patients with pregnancy complications. Am J Obstet Gynecol 2005;193:1698-702.

40. Kaygusuz I, Firatli-Tuglular T, Toptas T, Ugurel V, Demir M. Low levels of protein $Z$ are associated with HELLP syndrome and its severity. Clin Appl Thromb Hemost 2011;17:214-9.

41. Gris JC, Quéré I, Dechaud H, Mercier E, Pinçon C, Hoffet $\mathrm{M}$, et al. High frequency of protein $\mathrm{Z}$ deficiency in patients with unexplained early fetal loss. Blood 2002;99:2606-8. 